УДК 61:378.147(073).001.76

\title{
МОДЕРНІЗАЦІЯ НАВЧАЛЬНИХ ПЛАНІВ І ПРОГРАМ ПІДГОТОВКИ ЛІКАРІВ ВІДПОВІДНО ДО НОВОЇ ПАРАДИГМИ РОЗВИТКУ ЄВРОПЕЙСЬКОГО ОСВІТНЬОГО ПРОСТОРУ
}

\author{
В. Ф. Москаленко, О. П. Яворовський, І. С. Булах, Л. І. Остапюк \\ Національний медичний університет імені О. О. Богомольияя
}

\section{MODERNIZATION OF CURRICULUM AND PROGRAMS OF TRAINING OF DOCTORS IN ACCORDANCE WITH NEW PARADIGM OF DEVELOPMENT OF EUROPEAN EDUCATIONAL RANGE}

\author{
V. F. Moskalenko, O. P. Yavorovskyi, I. Ye. Bulakh, L. I. Ostapiuk \\ National Medical University by O. O. Bohomolets
}

\begin{abstract}
Стаття розкривас інноваційні дидактичні та комп'ютерні технології, впроваджені у навчальний процес на додипломному етапі підготовки лікарів та на факультеті підвищення кваліфікації викладачів.
\end{abstract}

The article reveals innovative teaching and computer technology incorporated in the educational process at the undergraduate stage of training of physicians and at the faculty of professional development of teachers.

Вступ. Велика хартія університетів - Magna Charta Universitatum [1], підписана європейськими університетами у 1988 р., дає визначення справжньому університету як центру культури, знань та досліджень, декларує неподільність викладання та дослідницької роботи як основний принцип діяльності.

Країнами-учасницями Болонського процесу 2010 рік був визнаний роком завершення побудови Європейського простору вищої освіти (СПВО). Водночас комюніке, прийняті міністрами освіти у Льовені/Лувенля-Ньов 2009 року [2] та Будапешті/Відні 2010 року [3], відмітили, що ЄПВО створений не повністю, не всі засади Болонського процесу реалізовані. Проте відмічено ряд досягнень за 10 років його розбудови та продовжено остаточне формування до 2020 р.

Комюніке 2012 р. у Бухаресті [4] відмічає, що болонські реформи змінили обличчя вищої освіти в Європі, завдяки участі та самовідданості вищих навчальних закладів, співробітників і студентів. В Комюніке європейських міністрів освіти (2009-2012рр.) задекларовані такі пріоритети подальшого розвитку СПВО: завершення розробки національних структур кваліфікацій, реалізація рекомендацій стратегії "Мобільність для кращого навчання" (як мінімум 20 \% випускників повинні пройти період навчання або практику за кордоном), розвиток студентоцентрованого навчання з впровадженням інноваційних технологій та наукових досліджень, широка участь сту- дентів в управлінських структурах закладів на всіх рівнях, консультування міжнародними агентствами діяльності ВНЗ та залучення цих агентств до сертифікації на відповідність міжнародним стандартам.

Основна частина. Враховуючи визначені у Великій хартії університетів та в зазначених комюніке пріоритети подальшої розбудови Європейського простору вищої освіти до 2020 р., особливості та надбання національної освітньої системи, досвід ВМНЗ України, в т. ч. нашого університету, в НМУ імені О. О. Богомольця (далі - Університет) розроблені Концепція розвитку НМУ імені О. О. Богомольця на 2011-2017 pp. та Перспективний комплексний план розвитку НМУ імені О. О. Богомольця на 20112017 pp., затверджені Конференцією трудового колективу та Вченою радою закладу.

У цих документах наведено комплекс системних заходів із забезпечення динамічногоінноваційного розвитку Університету для досягнення визнання як міжнародного науково-освітнього медичного центру на теренах європейського співтовариства, підвищення конкурентоспроможності наукових досліджень та їх результатів, досягнення міжнародних стандартів якості освітніх послуг, утримання стійкого економічного зростання і гарантованого виконання соціальних зобов'язань, морально-етичного і духовного розвитку колективу.

У 2011 році НМУ імені О. О. Богомольця став учасником Великої хартії університетів. Цим актом Уні-

( ) В. Ф. Москаленко, О. П. Яворовський, І. Є. Булах, Л. І. Остапюк 
верситет підтвердив свою належність до академічної співдружності університетів Свропи і, як сучасний вищий медичний навчальний заклад, будує свою діяльність та створює науково-методичний супровід інноваційного розвитку відповідно до ії принципів.

Упровадження засад Болонського процесу, оновлення інформаційного, навчально-методичного забезпечення, впровадження сучасних інноваційних дидактичних та комп'ютерних технологій здійснюються 3 урахуванням результатів науково-дослідних робіт (НДР) фахівців Університету психолого-педагогічного спрямування.

За останні 10 років завершена робота над $25 \mathrm{HДР,}$ продовжується виконання 17 НДР науково-методичного спрямування.

Нормативно-правовими документами з вищої освіти приділяється особлива увага удосконаленню системи управління якістю у вищих навчальних закладах, яка б відповідала кращим національним та міжнародним зразкам. Виконанню цих завдань в НМУ імені О. О. Богомольця сприяє діяльність сектору моніторингу якості освіти та соціологічної групи, які проводять на відповідному науково-метричному рівні моніторингові дослідження щодо всіх напрямків діяльності закладу: стосовно змісту медичної освіти, відповідності нормативним вимогам навчально-методичних документів, форм, методів та контролю результатів навчання. Разом з органами студентського самоврядування та представниками іноземних земляцтв протягом навчального року проводиться анонімне анкетування студентів та лікарів-інтернів, слухачів, клінічних ординаторів, аспірантів, докторантів щодо фактів негативних явищ, якості навчально-виховної роботи, умов проживання в гуртожитках, оцінки діяльності адміністрації Університету. Сектором моніторингу якості освіти розроблені програми перевірки діяльності кафедр, деканатів на виконання чинних положень про діяльність цих підрозділів.

Важливим питанням удосконалення якості освітнього процесу присвячена науково-дослідна робота “Науково-методичний супровід впровадження у медичній освіті державних та міжнародних стандартів управління, моніторингу і забезпечення якості”, яка виконується фахівцями Університету на замовлення MO3 України. Порівняльний аналіз вимог міжнародних та вітчизняних стандартів забезпечення якості освіти дозволив розробити сучасні підходи до запровадження менеджменту якістю освітнього процесу в Університеті, оновити на основі процесного підходу до управління якістю Положення про кафедру, про факультет, внести доповнення до Інструкції про сис- тему оцінювання навчальної діяльності студентів за умови КМСОНП, створити Положення про інтегрований функціональний підрозділ сприяння працевлаштуванню випускників, які навчаються за державним замовленням. 3 врахуванням міжнародних стандартів Всесвітньої федерації медичної освіти (базова медична освіта) розроблена Програма внутрішнього аудиту діяльності закладу в цілому та його підрозділів (кафедр, факультетів), яка грунтується на використанні категорій та підкатегорій міжнародних стандартів ВФМО і дозволяє виявити проблеми та можливості подальшого розвитку Університету.

Важливим кроком з удосконалення науково-методичного супроводу розвитку сучасного медичного університету є розроблена та апробована виконавцями зазначеної науково-дослідної роботи методика зіставлення процесних та результативних показників якості діяльності ВМНЗ за результатами внутрішньоуніверситетського рейтингу, поточного та підсумкового модульного контролів 3 дисциплін та зовнішнього оцінювання МО3 України успішності навчання студентів (ліцензійного інтегрованого іспиту “Крок 1”). Отримані висновки дозволили керівництву Університету прийняти управлінські рішення щодо удосконалення системи підготовки до іспитів “Крок”.

Реалізації європейських засад неподільності викладання навчання та дослідницької роботи студентів, як важливого принципу діяльності сучасного університету, сприяє участь НМУ імені О. О. Богомольця у виконанні міжнародного проекту ТЕМПУС (MUMEENA) "Модернізація додипломної медичної освіти у країнах Східного Сусідства” (далі - Проект). Основними напрямками діяльності учасників міжрегіонального консорціому є:

- модернізація навчального плану (раннє формування дослідницьких навичок у студентів, впровадження інтерактивних практичних занять з розвитку клінічного мислення на основі ситуаційних завданьклінічних кейсів, внесення питань з геронтології та геріатрії до робочих навчальних програм 3 природничо-наукових тапрофесійно-орієнтованих дисциплін); - створення тренінгового центру для викладачів.

Викладачі Університету, учасники проекту пройшли стажування у Медичному центрі Університету Утрехта (Нідерланди), в університетах Лідсу (Великобританія) та Гренади (Іспанія), у Тбіліському державному медичному університеті (Грузія).

В листопаді 2012 р. на базі НМУ імені О. О. Богомольця відбулась міжнародна конференція за участю європейських країн - учасниць проекту ТЕМПУС (MUMEENA) (далі - Конференція). 
Отриманий в результаті стажування зарубіжний досвід, рішення учасників Конференції, національні, інституціональні, науково-методичні та дидактичні надбання слугували підгрунтям для упровадження в навчально-виховний процес інноваційних психологопедагогічних та комп'ютерних технологій навчання.

Учасниками Проекту розроблена Робоча навчальна програма елективного курсу “Основи наукових досліджень”, яка апробується в 2012/2013 н. р. зі студентами II курсу медико-психологічного факультету. Метою програми є сприяння формуванню особистості з творчим мисленням, набуття вміння виконати індивідуальні навчально-дослідні завдання як вид самостійної роботи студента під час вивчення навчальних дисциплін, планування та проведення наукового дослідження у науковому студентському гуртку, набуття навичок користування сучасними електронними науковими базами, оформлення реферативного викладу матеріалу, статті, курсової роботи тощо.

Враховуючи пропозиції студентів - членів наукового студентського товариства імені О. А. Киселя, розроблені наступні модулі робочої навчальної програми “Основи наукових досліджень” (елективний курс) на III-V курсах для подальшого упровадження.

Проведена відповідна робота щодо адаптації програми "Розвиток клінічного мислення на основі ситуаційних завдань - клінічних кейсів”, яка успішно використовується в Медичному центрі Університету Утрехта (Нідерланди), до навчання студентів НМУ імені О. О. Богомольця.

Фахівцями Університету розроблені методичні рекомендації для викладачів-консультантів та студентів, які будуть виконувати функції викладачів, щодо раннього формування основ клінічного мислення при викладанні медико-біологічних та пропедевтичних клінічних дисциплін з використанням клінічно-орієнтованих ситуаційних завдань. Внесені доповнення до змісту робочих навчальних програм з патоморфології, патофізіології, пропедевтики внутрішньої медицини щодо інтерактивної методики проведення занять та розгляду клінічних ситуаційних завдань, таких, як “Жовтяниця", “Гарячка”, “Набряки ніг”, “Загальна гнійна інфекція”, “Гіпертонічний криз” та ін. На інтерактивних практичних заняттях будуть використовуватись структуровані міні-кейси, які призначені для оцінки знань, розумінь, вміння аналізувати навчальний матеріал студентами тощо.

Зважаючи на те, що самостійна робота студента (CРC) значною мірою визначає якість підготовки фахівців, закладає підвалини подальшого самостійно- го навчання лікаря впродовж професійного життя та $\epsilon$ складовою кредитів, в Університеті приділяється значна увага упровадженню нових активних методів СРС, орієнтованих на дослідницьку діяльність. Серед таких - самостійна розрахункова графічна робота студентів 3 дисципліни "Медична інформатика", яка передбачає набуття досвіду користування науковою літературою, в т. ч. - сучасними електронними базами медичних даних, вміння аналізувати, застосовувати інформаційні та комп'ютерні технології, формує вміння оформити та публічно (на практичному занятті) захистити самостійно розроблений проект. Такій же меті слугує СРС з підготовки студентів до аналітико-синтезуючих занять після вивчення змістових модулів 3 дисципліни “Анатомія людини”.

Під час вивчення клінічних дисциплін широко застосовується на кафедрах, як самостійна робота студентів, графологічне структурування діагностичних заходів при різних захворюваннях, алгоритмів диференційної діагностики захворювань та їх лікування, розробка студентами графів логічної структури синдромів та симптомів, передбачених в освітньо-кваліфікаційній характеристиці. Це вимагає грунтовних знань з відповідної дисципліни, уміння аналізувати, узагальнювати та структурувати інформацію студентами 45 курсів під час самопідготовки до навчальних занять.

Діяльність в НМУ імені О. О. Богомольця факультету підвищення кваліфікації викладачів ВМНЗ України (далі-ФПК) спонукає до пошуку інноваційних форм і методів навчання, створення нових структурних підрозділів в Університеті. Кафедрою медичної інформатики та комп'ютерних технологій навчання як опорною розроблена Програма для слухачів ФПК, кінцевою метою якої є формування дослідницьких навичок слухачів засобами сучасних електронних медичних баз даних 3 використанням методології доказової медицини.

Тематика навчальних занять зі слухачами стосується основних понять, принципів і завдань доказової медицини, контрольованих клінічних досліджень як джерел доказів, сучасних інформаційних ресурсів, структури Кохрейнівської бібліотеки, інтернет-ресурсів доказової медицини тощо.

Впровадженню інноваційних технологій на ФПК сприяє створення в Університеті Тренінгового центру для викладачів, в якому науково-педагогічні працівники клінічних кафедр опановують методологію, організаційні та методичні підходи до навчання студентів в умовах використання симуляційних технологій, розробляють сучасне методичне забезпечення практичних занять з використання симуляційних 
комп'ютерних програм, релевантні методи оцінювання результатів віртуального тренінгу.

Висновок. Подальша розбудова ЄПВО до 2020 року диктує необхідність упровадження інноваційних дидактичних та комп'ютерних технологій, поліпшення менеджменту освітнього процесу, удосконалення

\section{Література}

1. Велика хартія університетів, Болонья, 18 вересня 1988 р. -ww.osvita.org.ua

2. Комюніке Конференції Міністрів європейських країн, відповідальних за сферу вищої освіти, Льовен/Лювен-ляНьов, 28-29 квітня 2009 p. -www.mon.gov.ua

3. Комюніке Конференції Міністрів європейських країн, всіх аспектів діяльності ВМНЗ на їх відповідність Державним стандартам та міжнародному консенсусу оптимальної практики навчання у вищих медичних навчальних закладах, що є надійним шляхом гарантії якості та акредитації медичних університетів на міжнародному рівні.

відповідальних за сферу вищої освіти, Будапешт/Відень, 1112 березня 2010 p. - ww.mon.gov.ua

4. Комюніке Конференції Міністрів європейських країн, відповідальних за сферу вищої освіти, Бухарест, 26-28 квітня 2012 p. - www.tempus.org.ua 